\title{
WAWASAN NUSANTARA
}

\author{
Dedimus Kodi \\ IIK STRADA INDONESIA \\ dedimuskodi5@gmail.com
}

\begin{abstract}
ABSTRAK
Wawasan Nusantara merupakan salah satu konsepsi politik dalam ketatanegaraan Republik Indonesia. Perjuangan pengembangan Wawasan Nusantara ini masih terus berjalan. Konsepsi atau wawasan nusantara ini antara lain telah dan akan selalu mendukung kesatuan dan persatuan bangsa Indonesia perlu dipertahankan diperjuangkan dengan gigih didalam negeri atau di dunia Internasional. Namun demikian perlu disadari kesatuan dan persatuan yang merupakan titik sentral wawasan nusantara itu bukan merupakan satu-satunya isi dari wawasan nusantara. Dalam rangka memahami konsep Wawasan Nusantara menjadi melembaga pada semua komponen masyarakat Indonesia, adalah yang paling utama adalah menciptakan rasa nasionalisme kepada bangsa kita sendiri yang kaya akan segala potensi yang ada dialam Indonesia dan juga berusaha untuk dapat mempertahankan kesatuan dan persatuan kita untuk mempertahankan integritas bangsa Indonesia.
\end{abstract}




\section{LATAR BELAKANG}

Berdasarkan TAP MPR Tahun 1993 dan 1998ntentang GBHN, wawasan nusantara adalah cara pandang dan sikap bangsa indonesia, tentang jati diri dan lingkungan yang mengutamakan persatuan dan kesatuan bangsa, serta kesatuan wilayah demi tercapainya tujuan nasional. Ketetapan MPR tahun 1999 menyatakan: "Wawasan nusantara adalah cara pandang dan sikap bangsa mengenai diri dan lingkungan yang serba beragam dan bernilai strategis dengan menguamakan persatuan dan kesatuan bangsa serta wilayah dalam menyelenggarakan kehidupan bermasyarakat, berbangsa, dan bernegara dengan tujuan mencapai tujuan nasional."

Menurut para ahli, Wawasan Nusantara sebagai berikut:

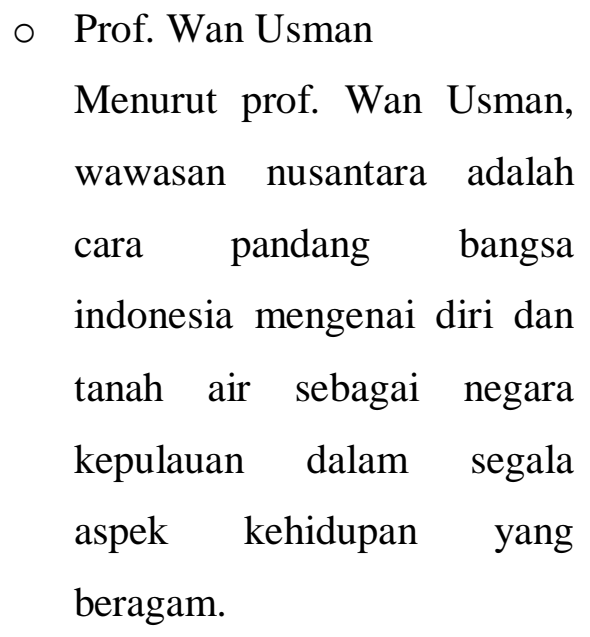

○ Munadjat Danusaputro, 1981

Menurut Munadjat

Danusaputro, wawasan nusantara adalah cara pandang bangsa indonesia tentang diri dan lingkungannya dalam eksistensi yang saling berhubungan serta penerapannya di tengah lingkungan berdasarkan asas nusantara. Asas nusantara sendiri merupakan suatu ketentuan dasar yang harus di taati, di patuhi dan di pelihara agar kepentingan nasional dapat terwujud. Cara pandang bangsa indonesia tentang diri dan lingkungannya juga harus sesuai dengan ide nasional pancasila, sebagaia aspirasi suatu bangsa yang merdeka, berdaulat dan bermartabat di tengah-tengan lingkungan yang menjiwai tindak kebijaksanaan dalam mencapai tujuan perjuangan bangsa.

○ M. Panggabean, 1979 
Menurut M. Panggabean,

Wawasan

nusantara

merupakan doktrin politik

bangsa indonesia untuk

mempertahankan

kelangsungan hidup NKRI

berdasarkan pancasila dan

UUD 1945 dengan

mempertimbangkan pengaruh

ekonomi, geografi,

demografi, teknologi, dan

peluang strategis lainnya.

Wawasan nusantara sebagai

geopolitik indonesia, dan

nilai yang terkandung di

dalam wawasan nusantara

telah di integrasikan dalam

lima aspek secara intern yaitu

kesatuan wilayah, kesatuan

bangsa, kesatuan ekonomi,

kesatuan budaya, dan

kesatuan pertahanan.

Sedangkan nilai ekstern nilai

integrasi di arahkan untuk

mewujudkan ketertiban dunia

yang berdasarkan kepada

kemerdekaan, perdamaian

abadi dan keadilan sosial.

- Sabarti Akhadiyah MK, 1997

Menurut Sabarti Akhadiyah, wawasan nusantara adalah cara pandang bangsa indonesia tentang diri dan lingkungannya sesuai dengan pancasila atau UUD 1945 sebagai bentuk aspirasi bangsa yang merdeka, berdaulat dan bermartabat yang menjiwai kebijakan dalam mencapai tujuan bangsa.

- Srijanti, Kaelan, dan Achmad Zubaidi, 2007

Menurut Srijanti, Kaelan, dan Achmad Zubaidi, wawasan nusantara ialah cara pandang bangsa terhadap diri dan lingkungannya berdasarkan pancasila dan UUD 1945, serta sesuai wilayah geografis nusantara yang menjiwai kehidupan bangsa demi mencapai tujuan dan cita-cita nasional.

○ Sumarsono, 2002

Menurut sumarsono, wawasan nusantara merupakan nilai yang menjiwai segenap peraturan perundang-undangan pada setiap strata di seluruh wilayah negara, sehingga 
menggambarkan sikapa dan

perilaku, paham serta

semangat kebangsan atau

nasionalisme yang tinggi dan

merupakan identitas atau jati

diri bangsa indonesia.

Wawasan nusantara sebagai cara pandang Bangsa Indonesia tentang merupakan gejala sosial yang dinamis dengan tiga unsur:

- Wadah dari wawasan nusantara adalah wilayah Negara kesatuan RI berupa nusantara dan organisasi negara RI sebagai kesatuan utuh.

- Isi wawasan nusantara adalah inspirasi bangsa indonesia berupa cita-cita nasional berdasarkan pancasila dan UUD 1945.

- Tata laku dari wawasan nusantara adalah tindakan bangsa indonesia untuk melaksanakan falsafah pancasila dan
UUD 1945 yang apabila di laksanakan dapat menghasilkan wawasan nusantara.

\section{RUMUSAN MASALAH}

1. Apa itu wawasan Nusantara

3. Bagaimana cara Perwujudan Kepulauan Nusantara sebagai satu Kesatuan Politik, Kesatuan Sosial dan Budaya, Kesatuan

Ekonomi, serta Kesatuan Hankam?

\section{TUJUAN}

1. Untuk memahami wawasan Nusantara

2. Memenuhi tugas kuliah

3. Bembahas cara Perwujudan Kepulauan Nusantara sebagai satu Kesatuan Politik, Kesatuan Sosial dan Budaya, Kesatuan

Ekonomi, serta Kesatuan Hankam

\section{PEMBAHASAN}

\subsection{Pengertian Wawasan Nusantara secara etimologi}

Wawasan nusantara merupakan cara pandang terhadap bangsa dengan tujuan menjaga persatuan dan kesatuan, yang di wujudkan untuk mengutamakan kepentingan nasional di banding kepentingan pribadi , kelompok atau golongan tertentu. Wawasan 
Nusantara secara etimologi berasal dari bahasa jawa wawas yang berarti pandangan, nusa yang berarti kesatuan kepulauan dan antara yang bermakna dua samudra. Jadi secara umum wawasan Nusantara adalah cara pandang atau cara melihat kesatuan kepulauan yang terletak di antara (Asia dan Australia) juga dua samudera (Hindia dan Pasifik).

Dalam mencapai tujuan Pembangunan Nasional mencakup beberapa aspek kesatuan, seperti kesatuan politik, ekonomi, sosial budaya, dan pertahanan keamanan (hankam).

\subsection{Cara Perwujudan Kepulauan}

Nusantara sebagai satu Kesatuan Politik, Kesatuan Sosial dan Budaya, Kesatuan Ekonomi, serta Kesatuan Hankam

Indonesia adalah negara yang memiliki berbagai keragaman di dalamnya. Misalnya dlihat dari suku bangsanya, negara ini terdiri dari berbagai suku seperti Jawa Sunda, Dayak, Bugis, dan sebagainya. Dari setiap suku bangsa memiliki beraneka budaya yang memperkaya corak budaya asli Indonesia.

Semua keanekaragaman tersebut memerlukan persatuan. Dengan persatuan, maka semua yang tampak berbeda itu dapat bersatu sebagai kebulatan yang utuh. Dan, bersatu bangsa didorong dari kemauan secara sadar dan penuh tanggung jawab dalam mencapai kehidupan bangsa yang bebas di suatu wadah negara merdeka, berdaulat, adil, dan makmur.

\section{A. Definisi atau Arti Kesatuan Bangsa}

Saat persatuan bangsa tercipta, maka muncul kesatuan bangsa. Menurut buku PPKN Kelas XI (Kemdikbud 2017), kesatuan bangsa adalah kondisi yang utuh yang memperlihatkan keamanan, kesentosaan, dan kejayaan. Oleh sebab itu, unsur aman, sentosa, dan jaya bisa didapatkan ketika sudah tercipta kondisi kesatuan bangsa.

Menurut laman Kementrian Keuangan, persatuan dan kesatuan adalah prasyarat utama jika ingin melakukan pembangunan di suatu negara. Dalam kemajemukan masyarakat diperlukan kemampuan menjaga, mengembangkan, dan mewujudkan persatuan dan kesatuan di dalam kehidupan masyarakat.

Sementara itu, wujud kesatuan bangsa dapat ditinjau dari berbagai sisi seperti politik, ekonomi, sosial budaya, dan pertahanan keamanan. Berikut ini perwujudan kesatuan tersebut dalam beberapa aspek kehidupan. 


\section{B. Perwujudan Kepulauan Nusantara} Sebagai Kesatuan Politik

- Keutuhan wilayah nasional dengan semua isi dan kekayaannya adalah satu kesatuan wilayah, wadah, ruang hidup, dan kesatuan mitra seluruh bangsa, serta menjadi modal dan milik bersama bangsa.

- Bangsa Indonesia yang terdiri berbagai suku dan bahasa, memeluk dan meyakini berbagai agama dan kepercayaan terhadap Tuhan YME, merupakan satu kesatuan bangsa yang bulat dalam arti seluas-luasnya.

- Secara psikologis, bangsa Indonesia merasa satu, senasib sepenanggungan, sebangsa, dan setanah air, serta bertekad mencapai cita-cita bangsa.

- Pancasila dalah satu-satunya falsafah serta ideologi bangsa dan negara, yang melandari, membmbin, dan mengarahkan bangsa ke tujuannya.

- Kehidupan politik di Nusantara adalah satu kesatuan politik yang dilakukan berdasar Pancasila dan UUD 1945.

- Seluruh kepulauan Nusantara adalah kesatuan hukum yang hanya ada satu hukum mengabdi pada kepentingan nasional.

- Bangsa Indonesia hidup berdampingan dengan bangsa lain, ikut menciptakan ketertiban dunia berdasarkan kemerdekaan perdamaian abadi, dan keadilan sosial melalui politik luar negeri bebas aktif lalu diabadikan bagi kepentingan nasional.

\section{Perwujudan Kepulauan Nusantara Sebagai Kesatuan Ekonomi}

- Wilayah Nusantara adalah modal dan milik bersama bangsa, keperluan hidup sehari-hari mesti tersedia merata di seluruh wilayah tanah air.

- Tingkat perkembangan ekonomi harus serasi dan seimbang di seluruh daerah.

- Kehidupan perekonomian di seluruh wilayah Nusantara adalah satu kesatuan ekonomi yang diselenggarakan untuk usaha berdamai berdasar asas kekeluargaan dan ditujukan bagi kemakmuran rakyat.

D. Perwujudan Kepulauan Nusantara Sebagai Kesatuan Sosial Budaya 
- Masyarakat Indonesia adalah satu, perikehidupan bangsa adalah kehidupan yang serasi dengan tingkat kemajuan masyarakat yang sama, merata, dan seimbang lalu adanya keselarasan kehidupan yang sesuai kemajuan bangsa.

- Budaya Indonesia hakikatnya satu. Corak ragam budaya menggambarkan kekayaan budaya sebagai modal dan landasan pengembangan budaya bangsa seluruhnya, yang hasilnya dapat dinikmati seluruh bangsa Indonesia.

\section{E. Perwujudan Kepulauan Nusantara Sebagai Kesatuan Hankam}

- Ancaman terhadap satu daerah hakikatnya ancaman bagi seluruh bangsa dan negara.

- Tiap-tiap warga negara mempunyai hak dan kewajiban yang sama di dalam pembelaan negara.

\section{KESIMPULAN}

Dari pembahasan di atas dapat menyimpulkan secara umum Wawasan Nusantara adalah

keutuhan nusantara/nasional, dalam pengertiannya yaitu cara pandang yang secara utuh menyeluruh dalam lingkup nusantara dan demi kepentingan nasional. Bangsa Indonesia memiliki berbagai budaya yang tersebar diseluruh wilayah.

\section{DAFTAR PUSTAKA}

Sodik, M. A. (2018, September). Analysis of Improved Attitude of Youth in HIV/AIDS Prevention through the Provision of Health Education with Peer Education. In The 2nd Joint International Conferences (Vol. 2, No. 2, pp. 495-502).

Sodik, M. A., \& Setyani, A. T. (2018). Effect of Smoking For Teens Against Behavior and Social Interaction.

Sodik, M. A., Suprapto, S. I., \& Pangesti, D. (2013). Faktor-Faktor Yang Berhubungan Dengan Pelaksanaan Pelayanan Prima Pegawai Di Rsui Orpeha Tulungagung. STRADA Jurnal Ilmiah Kesehatan, 2(1), 24-32.

Kodi, D. (2021). Persatuan Dan Kesatuan Negara Indonesia.

Kodi, D. (2021). Demokrasi Dan Budaya Politik Indonesia.

Kodi, D. (2021). Hak Untuk Mendapatkan Pelayanan Kesehatan Sebagai Warga Negara Indonesia. 